\title{
Application of Ecological Modernisation in Sand Winning in Building Construction in Tamale, Ghana
}

\author{
Inusah Abu \\ and \\ Kenneth Peprah \\ (Corresponding Author) \\ kpeprah@uds.edu.gh \\ Department of Environment and Resource Studies \\ Simon Diedong Dombo University of Business and \\ Integrated Development Studies, Wa \\ DOI//http://dx.doi.org/10.4314/gjds.v17i2.1
}

\begin{abstract}
Sand is a raw material in the building and construction industry. Its sustainable supply is required to support infrastructure development in emerging cities in Ghana and elsewhere. However, sand is not adequately recognised as building construction foundational material, and is not sufficiently addressed by policy, planning, legislation and institutional management and remains a grey area in mainstream research. The increasing population in Tamale requires shelter which leads to exploitation of more sand. This study assessed sand winning from the periphery to support the core, Tamale. The study adopted crosssectional design with a mixed method approach. It involved a primary target of 200 sand winners and a secondary target of 59 household heads in a multi-stage sampling. Primary data were generated using questionnaire, key informant interview guide and personal observation. Data were analysed using Statistical Package for Social Scientists' descriptive statistics, central tendencies and cross tabulation with chi square test. The results showed that sand winning was done in six districts outside Tamale Metropolitan Assembly. Sand was winned from riverbeds, river walls and sand deposits. Sand winners preferred the use of manual labour to excavators. Sand winning provided livelihoods for tipper truck drivers and loading boys. Government regulation of the activity is limited and unsatisfactory. There was cordial relationship between sand winners and sand winning communities. It is recommended that government creates an agency to manage sand winning.
\end{abstract}


Keywords: Sand Winning, Concretisation, Ecological Modernisation, Tipper Truck, Tamale

\section{INTRODUCTION}

Global development is characterised by the number of people living in urbanised areas. Urban population of the world increased from 30\% in the 1950 os to $55 \%$ in the 2020s (UN, 2019). However, the rate of growth in large cities are often much faster than that of total population growth (WHO, 1991). In the process of urbanisation, occupation, life style, behaviour and socio-economic activities are transformed resulting in tremendous changes in the built environment to complete the urbanisation process (UN, 2019). The fastest growing cities are located in Africa (JICA, 2013). The African urban population increased from $28 \%$ in 1980 to $37 \%$ in 2006 (Asoka, Thuo \& Bunyasi, 2013). However, Africa's urbanisation is described as one with debilitating socio-economic and environmental consequences and Ghana is not an exception (Cobbinah \& Erdiaw-kwasie, 2016). In Ghana, urban population has increased from 9.4\% in 1931 to 50.9\% in 2012 (Ghana Statistical Service [GSS], 2012). Whereas the country has risen from low income label to middle income status during its urbanisation process, some negative accolades such as urban slums and urban blight could not be avoided in some parts of the major cities of Accra-Tema, Kumasi, Sekondi-Takoradi and Tamale (World Bank, 2014). Also, other cities have reached similar urban growth like that of Ghana's four main cities but with far better built environment. The explanation is done severally beginning with poverty and its ramifications, inadequate land tenure security, policy, regulation, management and resource constraints (World Bank, 2017). This study, however, identifies that the role of sand in Ghana's urbanisation requires far deeper recognition when analyzing resource constraints. In Tamale, the population has increased from 40,443 in 1960 to 371,351 in 2010 (Fuseini et al., 2017). The increase in human numbers lags behind housing and other shelter needs for offices, markets, hospitals, recreation among others. Development of infrastructure rests on individuals, non-governmental groups and government. Sand is needed among other materials to carry out the construction activities. The dynamics of sand winning is analysed under ecological modernisation framework.

Developing countries are categorised by indicators such as low per capita real income, high population growth rate, high rates of unemployment, dependency on primary sector of the economy and dependence on exports of primary commodities (Agarwal, 2019). We add that concretisation is another indicator of developing countries. Hereafter, concretisation refers to concrete made up of water, 
rock, gravel, sand and cement. Developing countries are at various levels of using concrete to produce roads, bridges, homes/houses and other building infrastructure (Saviour, 2012). Upon entering a developing country, the site of the number of uncompleted basic infrastructural projects is the first visible sign of a country going through the development process. However, concretisation is not development but the wheel that propels the development process. Besides cement which is a factory product (Portland cement), sand is the next most important component in concretisation. Sand is obtained from the bank of natural resources provided by the natural environment (Sumani, 2019). Although there is no contention over concretisation, sand is produced illegally all over Ghana and state security are either cramping down on sand winning or giving it a blind eye. How could such an important resource in national development process not given proper management by the state? Hence, there is the paradox of producing sand illegally to make concrete and to build the basic infrastructure to aid national development. The literature shows that sand is not adequately recognised as building construction foundational material, and is not sufficiently addressed by policy, planning, legislation and institutional management and remains a grey area in mainstream research (Peduzzi, 2014).

This article is significant in the sense that it contributes to a wake-up call on the international community to help developing countries to ensure that sand winning meets sustainable standards. Sustainability in sand winning is to ensure the achievement of SDG 11 in general and target 11.1 (housing) and target 11.2 (roads) specifically. This should be tied in with sustainable production and consumption (SDG 12), particularly, target 12.2 (sustainable management and efficient use of natural resources). Consequently, this process leads to conservation, restoration and sustainable use of the larger ecosystems (SDG 15.1) in which sand is naturally formed into a resource. At the national level, this paper contributes to the solution to the urban housing deficit, poor-quality housing that fails to meet the minimum standards set by the UN, urban slums sprawling and urban infrastructure gap (MLGRD, 2012, GSS, 2014). The solution to these challenges require the use of large quantum of sand in the making of bricks, mortar and concrete. A social theory of ecological modernisation is used to explain this study. Its main principle is that environmental protection is not a barrier to growth. Ecological modernisation insists on stringent environmental policy to ensure economic efficiency and technological innovation (Berger et al., 2001).

The problem investigated by this paper entails naturally occurring sand in riverbeds, riverine areas, wetlands, swamps, floodplains and savannah agricultural 
lands that are mined by indigenous or local people (Ghanaian citizens) for sale to the construction industry. The processes include identification of sand rich deposit, negotiation with the private landowner or not, the use of heavy machinery or simple tools (pick axe and shovel) to gather the sand. In all cases, there are tipper trucks responsible for the transportation of the sand. There is no involvement of Ghana's Environmental Protection Agency or any other relevant state institution. State security move in with force to stop the operations only when significant rivers, wetlands and massive agricultural lands are affected by the activities of the sand winners/miners. Ad hoc measures abound in different administrative regions and districts of the country concerning sand winning. In the selected case study, Tamale Metropolitan area is one of the fastest growing metropolis in Ghana. There is increasing demand for housing for the progressively growing population, offices, social services and businesses. Sand is needed for not only housing but urban roads and other government and private sector infrastructure. The implications of sand winning to meet the huge demand is felt by satellite communities surrounding the metropolis which play host to the sand deposits. However, the attention of government, donors, the international community and even academics (research) have focused on the infrastructural gaps (Raghavendra \& Hans, 2012), housing deficits, urban slums (United Nations Human Settlements Programme [UNHabitat], 2003), and urban poor (Acharya, 2010) at the expense of the natural environment that provide the raw materials to solve these problems. We argue that the infrastructural development of Tamale Metropolis is necessary as well as the natural resources, particularly, sand that is harnessed to satisfy the constructional needs.

Therefore, the overarching research question is: How do we achieve win-win scenario for Tamale's constructional development and sand winning? Specifically, this study assesses: the environmental concerns of sand winning regarding spatial distribution of the activities around the Metropolis; the monetary or financial gains (economic viability) of sand winning to the sand winners/miners; the social capital shared by the sand deposit communities, Tamale Metropolis and the sand winners/ miners; and, sustainability concerns observed by stakeholders in the sand winning.

\section{Theoretical Underpinnings}

The theory of ecological modernisation anchors this study. Illegal sand winning problem can be explained theoretically as human and environment linkages that can be handled by human ecology tradition, ecological modernisation school of thought and postmodern view of the environment (Mol and Spaargaren, 2000). 
Ecological modernisation advances 'the discourse that recognises the structural character of the environmental problematique but nonetheless assumes that existing political, economic, and social institutions can internalise the care for the environment' (Langhelle, 2000:306). Also, it can be considered 'as the social scientific interpretation of environmental reform processes at multiple scales in the contemporary world' (Mol et al., 2014:2). Ideally, ecological modernisation 'aims at the same time for the improvement of ecological and economic efficiency (Ja"nicke, 1988, p. 23, our emphasis)' (Andersen and Massa, 2000:337). Hence, it is based on the principle of preventive environmental policy and social market economy. In German, Vorsorge (prevention rather than cure) and Vorsprungdurch Technik (advancement through technology) (Andersen and Massa, 2000:337). Furthermore,

... the precautionary approach was defined officially as one in which damages done to the natural world (which surrounds us all) should be avoided in advance and in accordance with opportunity and possibility. The precautionary principle further means the early detection of dangers to health and environment by comprehensive, synchronised research, in particular about cause and effect relationships . . . it also means acting when conclusively ascertained understanding by science is not yet available. Precaution means to develop, in all sectors of the economy, technological processes that significantly reduce environmental burdens ... (Andersen and Massa, 2000: 339)

From the foregoing, the study proceeds on the following assumptions captured in equations 1,2 and 3.

Ecological modernisation $=$ political programme or policy discourse $\quad$ Eq 1

Political programme or policy discourse = radical environmental reform Eq 2

Radical environmental reform $=\mathrm{f}$ (technological optimism + government institutional arrangements + free market capitalism + human agency + reflexivity + [social + natural environment $]+[$ sustainable production + consumption $]+[$ natural science + social science] + [epistemological empiricism + social constructivism]) Eq 3

Table 1 shows explanation of the terminologies used in equation 3. 
Table 1: Meaning of terms in ecological modernisation

\begin{tabular}{|c|c|c|}
\hline $\mathrm{S} / \mathrm{N}$ & $\begin{array}{l}\text { Terminologies } \\
\text { of Ecological } \\
\text { Modernisation }\end{array}$ & Meaning of Terms \\
\hline 1 & $\begin{array}{l}\text { Technological } \\
\text { Optimism }\end{array}$ & $\begin{array}{l}\text { The concept of ecological modernisation implies that it is } \\
\text { possible, through the development of new and integrated } \\
\text { technologies, to reduce the consumption of raw materials, as } \\
\text { well as the emissions of various pollutants, while at the same } \\
\text { time creating innovative and competitive products (Andersen \& } \\
\text { Massa, 200o:337). Advancing through technology. }\end{array}$ \\
\hline 2 & $\begin{array}{l}\text { Government } \\
\text { Institutional } \\
\text { Arrangements }\end{array}$ & $\begin{array}{l}\text { Government intervention and subsidies (e.g. government } \\
\text { support in research to come out with innovative ways of } \\
\text { resource exploitation and pollution reduction). }\end{array}$ \\
\hline 3 & $\begin{array}{l}\text { Free Market } \\
\text { Capitalism }\end{array}$ & $\begin{array}{l}\text { Innovative business approaches that can complement that } \\
\text { of government towards technological advancement in a free } \\
\text { market economy }\end{array}$ \\
\hline 4 & Human Agency & $\begin{array}{l}\text { Visionary human beings who will bring about the innovations } \\
\text { in technology }\end{array}$ \\
\hline 5 & Reflexivity & $\begin{array}{l}\text { Technicians and engineers in company to develop clean } \\
\text { technologies (Andersen \& Massa, 20oo) }\end{array}$ \\
\hline 6 & $\begin{array}{l}\text { Social + Natural } \\
\text { Environment }\end{array}$ & $\begin{array}{l}\text { Human, social and technical space on the one hand and natural } \\
\text { and environmental resources on the other hand }\end{array}$ \\
\hline 7 & $\begin{array}{l}\text { Sustainable } \\
\text { Production }+ \\
\text { Consumption }\end{array}$ & $\begin{array}{l}\text { Modernise production to make efficient the work of the } \\
\text { environment (production rationalisation) and culturally } \\
\text { palatable life styles in consumption patterns (Andersen \& } \\
\text { Massa, 200o). }\end{array}$ \\
\hline 8 & $\begin{array}{l}\text { Natural Science + } \\
\text { Social Science }\end{array}$ & $\begin{array}{l}\text { The use of natural and social sciences to detect possible dangers } \\
\text { as well as science and technology development }\end{array}$ \\
\hline 9 & $\begin{array}{l}\text { Epistemological } \\
\text { Empiricism + Social } \\
\text { Constructivism }\end{array}$ & Regulatory philosophy of ecological modernisation \\
\hline
\end{tabular}

Source: Andersen \& Massa (2000).

\section{METHODOLOGY}

Tamale is one of the four major towns in Ghana (Accra-Tema, Kumasi, SekondiTakoradi and Tamale). Its uniqueness makes it an appropriate choice for this study. This choice is justified on the grounds of its rapid horizontal sprawl at a rate of $4.4 \%$, (78\% spatial expansion between 2001 and 2014) (Fuseini \& Kemp, 2016). In addition to the growth in buildings are the progressive increase in both human and vehicular populations. Tamale is the first choice of any state-based economic intervention in northern Ghana, for example, university and other tertiary institutions, teaching and referral hospital, airport, military barracks and sports stadium. It remains 
the first choice for private sector initiatives, for example, it is the northern Ghana hub for local and international Non-Governmental Organisations and expatriate firms. Its geographic location on latitude $9^{\circ} 16^{\prime}$ and $9^{\circ} 34^{\prime}$ North and longitudes $0^{\circ} 36^{\prime}$ and $0^{\circ} 57^{\prime}$ West makes it a transit town between Accra-Tema and SekondiTakoradi seaports and landlocked countries of Burkina Faso and Mali. Tamale occupies a total land area of $922 \mathrm{~km} 2$ (Figure 1). Amidst, the potential for further growth and development are emerging challenges. "These challenges range from continuous production and maintenance of urban infrastructure and services to ensuring effective urban management in the economic, social and environmental sense of sustainability" (Fuseini et al., 2017:73). The undulating terrain is dissected by a drainage system formed mainly by the White and Red Volta and Sissili Rivers and their tributaries (Ghana Statistical Service, 2014). The banks of these rivers are natural deposits of sand for building constructional activities.

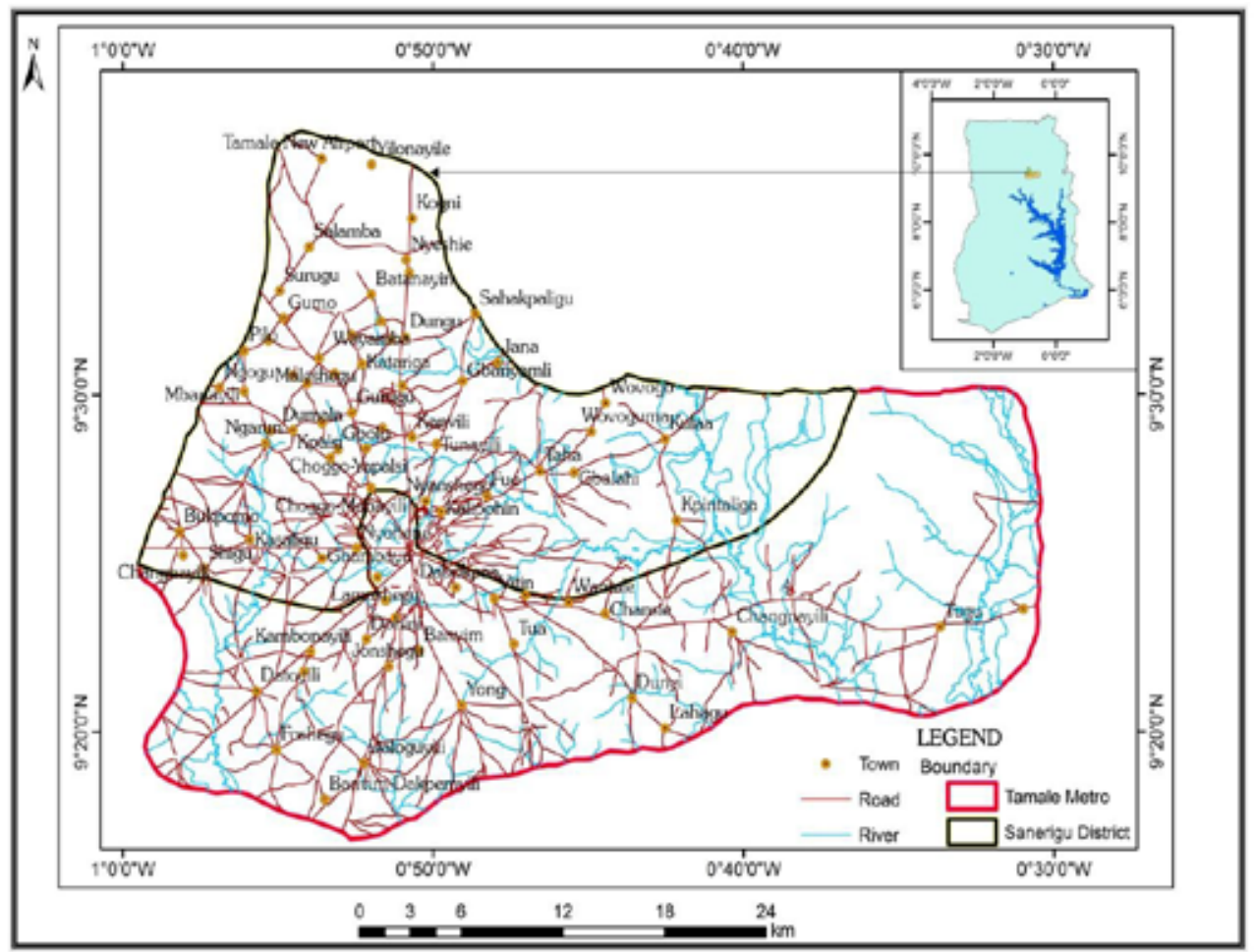

Figure 1: Map of Tamale Metropolitan area and sand deposit communities

Source: Town and Country Planning, Tamale (2014). 
The study adopted cross-sectional design with a mixed method approach. It involved a primary target of 200 sand winners and a secondary target of 59 household heads in a multi-stage sampling. At the first stage, Tamale represents a growth centre with huge demand for sand. This demand is satisfied by local entrepreneurs made of up sand winners (second stage, $n=200$ ). The final stage is occupied by owners of the sand deposit (host communities to the sand deposits, the land owners, $\mathrm{n}=59)$. The six host communities included with specific sample sizes are Dalun (6 respondents), Yapei (27), Kpalung (5), Dipali (7), Go (6) and Lingbunga (8). Relevant state institutions such as the Environmental Protection Agency (EPA), Ministry of Food and Agriculture (MoFA), the Forestry Commission and Land Commission offered a staff each to participate in the key informant interviews. Primary data were generated using questionnaire, key informant interview guide and personal observation. Data were analysed using Statistical Package for Social Scientists' descriptive statistics, central tendencies and cross tabulation with chi square test. Direct quotations from the key informant interviews were used to support findings from the survey.

Table 2: Sample size for drivers and loading boys

\begin{tabular}{|l|c|l|l|l|}
\hline Community & $\begin{array}{l}\text { Tipper trucks } \\
\text { Total Population }\end{array}$ & $\begin{array}{l}\text { Tipper trucks } \\
\text { drivers Sample } \\
\text { Size (95\%) }\end{array}$ & $\begin{array}{l}\text { Loading } \\
\text { boys Total } \\
\text { Population }\end{array}$ & $\begin{array}{l}\text { Loading boys } \\
\text { Sample Size } \\
\text { (95\%) }\end{array}$ \\
\hline Dalun & 150 & 70 & 50 & 23 \\
\hline Yapei & 50 & 23 & 17 & 8 \\
\hline Kpalung & 27 & 13 & 9 & 4 \\
\hline Dipali & 48 & 22 & 16 & 8 \\
\hline Go & 22 & 10 & 7 & 3 \\
\hline Lingbunga & 26 & 12 & 9 & 4 \\
\hline \multicolumn{1}{|c|}{ Total } & 323 & $\mathbf{1 5 0}$ & $\mathbf{1 0 8}$ & 50 \\
\hline
\end{tabular}

The philosophy of epistemological pluralism underpins the methodology of the study. It seeks a combination of critical realist perspective that there is reality out there irrespective of the researcher's knowledge of it and objective science tries to illuminate it; and, the social constructionist point of view that knowledge is constructed. The philosophical ontology that researcher and object of research are distinct (separate) be joined to the constructionist ontology of no separation between researcher and research object. In this case, the social sciences could use natural science tools and methods and proceed on the notion that the aim of science is to get it right about reality even though that appears impossible (Trochim, 2006). A dualism of philosophical ontology seems possible between epistemic subject and 
object distinction; and, no separation between subject and object. For sustainable winning and consumption of sand for the purposes of Tamale, epistemological pluralism and ontological dualism are needed to support research which requires interdisciplinary collaboration of natural and social sciences. This involves the use of pragmatic truth (what is useful or needful). Sand winning from sand deposits, river walls and beds and for the construction of Tamale do not fall squarely in either natural or social science. The issues involved are cross-cutting which demand the use of both sciences. The technology needed, conservation of biodiversity involved and reclamation of degraded land require physics, chemistry, biology, botany and even zoology for the wildlife as well as economics, political science, sociology, history and the cognate science of geography to ensure sustainable winning and consumption of sand.

\section{RESULTS AND DISCUSSION}

\section{The Environmental Concerns of Sand Winning}

It was revealed that all the sand winning sites are outside the geographical boundary of Tamale metropolitan area. This suggests that the peripheries (sand winning districts) are being exploited to develop the core, Tamale. The study revealed two extraction methods as manual extraction method and mechanical method (involving the use of excavators). From the 200 survey respondents, $94 \%$ (188 respondents) claim manual extraction is the dominant technology. Only 6\% (12 respondents) choose the use of machinery due to its impacts. Sand winners do not own the excavators. They are hired on daily basis at the cost of GHS2000.oo per day $(1 \mathrm{USD}=5.7 \mathrm{GHS})$. An excavator owner said:

The excavator consumes two (2) drums of fuel per day. Due to where the quality sand is located, excavator uses two (2) hours to do clearing and digging to load one term (loading 20 tipper trucks [4 axle ] = one term). One excavator loads 70 to 8 o tipper trucks (4 axle tipper trucks) a day.

The excavator technology does a lot more damage to the land than the manual method which uses simple cutlass to clear the land, pick axe to dig and shovel to lift sand into the truck. Therefore, higher technology means more damage and lower technology means less damage to the land. About 94.5\% (189 respondents) agree that using excavators destroy a lot more biodiversity, 3.5\% (7 respondents) mentioned the using pay loader and $2 \%$ (respondents) said using manual method. 
Furthermore, the quality of sand is determined by manual methods not machines. The results indicate that $57 \%$ (114 respondents) rob the sand between two fingers. The rest include $25 \%$ (50 respondents) test the sand's quality by seeing and feeling it, $12 \%$ (24 respondents) test the quality of sand through observation and $6 \%$ (12 respondents) by touching it in the palms.

Sand is used for plastering, concrete works and blocks making. Respondents revealed the source of sand for these various sand uses. In Table 3 majority of sand winners (60\%) extract plastering sand from sand deposit, 51.50\% take sand for concrete works from river walls and 58.50\% remove sand for block making from sand deposits. This shows that sand deposits in the savannah is the main source of sand for construction works in Tamale. In consonance with (Sayami and Tamrakar, 2007) traditional sites for sand winning are rivers, beaches and inland sand deposits.

Table 3: Sources of sand and various uses of sand

\begin{tabular}{|c|c|c|c|c|c|c|}
\hline \multirow{2}{*}{ Uses of sand } & \multicolumn{2}{|l|}{ Plastering sand } & \multicolumn{2}{l|}{ Concrete works } & \multicolumn{2}{l|}{ Block making } \\
\cline { 2 - 7 } & Frequency & \% & Frequency & \% & Frequency & \% \\
\hline Sand deposit & 120 & 60.0 & 70 & 35.0 & 117 & 58.5 \\
\hline River Walls & 47 & 23.5 & 103 & 51.5 & 53 & 26.5 \\
\hline River Bed & 33 & 16.5 & 27 & 13.5 & 30 & 15.0 \\
\hline Total & $\mathbf{2 0 0}$ & $\mathbf{1 0 0}$ & $\mathbf{2 0 0}$ & $\mathbf{1 0 0}$ & $\mathbf{2 0 0}$ & $\mathbf{1 0 0}$ \\
\hline
\end{tabular}

From Table 4 majority of the respondents (6o\%) hold the view that sand winning activity in Ghana is not regulated by government institutions. An interview with a staff of Administration of Stool Lands revealed that:

There is a legal framework regulating sand winning activities. However, it exists just as a broad policy for mining and not specifically to sand. Therefore, the concentration is on the high value minerals to the neglect of construction materials. The Assemblies (local government institutions) have failed to realise they have a role to play in the regulation of sand winning activity. 
Table 4: Perceptions on state regulation of sand winning

\begin{tabular}{|l|c|c|}
\hline \multicolumn{1}{|c|}{ Stated rules } & Frequency & $\mathbf{\%}$ \\
\hline No rule or regulation & 120 & 60.0 \\
\hline Existing & 62 & 31.0 \\
\hline Proposed & 4 & 2.0 \\
\hline Effective & 14 & 7.0 \\
\hline Total & $\mathbf{2 0 0}$ & $\mathbf{1 0 0}$ \\
\hline
\end{tabular}

About 98\% (196 respondents) have never received any training on sand winning and $2 \%$ (4 respondents) received training from environmentally friendly nongovernmental organisation. The sand winning activity goes on in a laissez-faire business manner.

An interview with an officer in the Department of Agriculture, Tamale Metropolitan area reveals his experience on the challenges associated with the enforcement of rules and regulations in sand winning:

Reclamation of the environment by planting trees after sand winning is necessary. However, high illiteracy among the sand producers makes it difficult to enforce the laws governing sand winning. Besides, the lack of support of opinion leaders has also challenged the success of implementing the rules governing the activities.

The results imply that limited stakeholder concerns on the environment and the consequences of sand winning in vulnerable communities are the main issues of poor sustainability. This has created a gap between the actual and potentials of the existing institutions in the implementation of strategies to sustain sand winning in support of constructional development in Tamale.

Meanwhile, the relevant environmental institutions such as Ministry of Lands and Natural Resources (MLNR), Ministry of Environment Science and Technology (MEST), Ministry of Food and Agriculture (MoFA), the Forestry Commission (FC), Minerals Commission and Environmental Protection Agency (EPA) keep a blind eye to the activities of sand producers. Often, a combined military and police force is used to stop encroachment on water bodies, especially, winning sand from river walls and beds. Earlier, Salifu (2016) found that local authorities fail to protect the environment and other livelihood activities from the operation of sand miners in the Bono Region. It emerged from Amponsah-Dacosta and Mathada (2017) that lack of clear cut guidelines constrains efforts of legislation enforcement and strategies to 
discourage indiscriminate extraction of sand as a factor affecting the sustainability of sand winning.

\section{The Monetary or Financial Gains - Economic Viability}

The district assembles, especially, Kumbugu District generated 1,500.00 GHS daily from the sand winners at Dalung (about 263 USD). At least, monthly generation was 45,000.00 (about 7895 USD). The traditional authority used part of their revenue to pacify the land to prevent evil-doers and for the safety of the sand winners and the entire district. A traditional ruler said: "We collect the moneys to pacify the land and prevent evil people".

It was the belief of the traditional Authorities that land is god, hence the pacification of the land with the money generated from the sand winners. This is in line with the findings which stated that in some societies in northern Ghana, land is god (Kpieta and Bonye, 2012).

The results indicate that $63.5 \%$ (127 respondents) respondents have their economic status improved to a high, $28.5 \%$ (56 respondents) said that their economic status have increased very high as a result of their involvement in sand winning. Also, 8.5\% (17 respondents) indicated that their economic status have increased moderately with their participation in sand winning. The scale is very high (increase properties by $80 \%$ to $100 \%$ per year), high (increase properties by $50 \%$ to $79 \%$ per year) and moderate (increase properties by $20 \%$ to $49 \%$ per year). In Table 5 , the results indicate that sand production and economic status improvement are not independent, the two are related. Also, the enhanced economic status varies among drivers and loading boys. This finding agrees with Arwa (2013) that sand winning benefits only a few people economically and Peprah (2013) that in Wa, Upper West Region drivers and loading boys benefits economically at the expense of local farmers.

Table 5: Effect of sand winning on economic status of respondents

\begin{tabular}{|l|c|c|c|}
\hline \multicolumn{1}{|c|}{ Level of effect } & Loading boys & Drivers & Row Totals \\
\hline Very high & $20(28.0)$ & $36(28.0)$ & 56 \\
High & $73(63.5)$ & $54(63.5)$ & 127 \\
Moderate & $7(8.5)$ & $10(8.5)$ & 17 \\
& & & 200 \\
\hline \multicolumn{1}{|c|}{ Column Totals } & $\mathbf{1 0 0}$ & $\mathbf{1 0 0}$ & \\
\hline
\end{tabular}

Numbers in brackets are percentages. 
The chi-square statistic is 7.9434. The $p$-value is 0.018842. Significant level 0.05 . If the $\mathrm{p}$-value is greater than the significance level of 0.05 , fail to reject the null hypothesis (accept the null hypothesis), that is, there is no significant relationship. If the p-value is less than 0.05 (reject the null hypothesis), it means there is significant association. Very High (80-100\%), High (50-79\%), Moderate (20-49\%)

Seasonality of sand winning is driven by two seasons: raining and dry seasons. During the dry season, sand winning goes on without any hindrance. However, the high supply of sand affects demand making it low. In the raining season, transportation of sand is impeded by unmotorable roads. Every time it rains, fresh sand is deposited on river walls and beds for collection by sand winners. However, the poor roads and frequent rains make winning goes down and demand for sand goes up. Over the years, sand winners have overcome the low supply in the raining season by heaping a lot of sand on higher grounds during the dry season. So in the raining season, they supply sand from the heap.

On scarcity of sand, the views of respondents indicate very high (2\%, 4 respondents), high (43\%, 86 respondents), moderate (25\%, 50 respondents) and low (28\%, 57 respondents). Generally, as sand winners continue to mine from these communities, sand deposits dwindle and become scarce. The distance between Tamale and sand mine sites becomes longer due to scarcity of sand.

The study shows that savings from income accruing from sand winning are low for 10\% (20 respondents), moderate (30\%, 60 respondents), high (35\%, 70 respondents) and very high (25\%, 50 respondents). With $\mathrm{N}=200$, chi-square statistics $=23.49, \mathrm{df}$ $=3$ asymp. and sig. (2-sided) = 0.0oo; a null hypothesis of no relationship between savings of loading boys and drivers and sand winning was formulated and the results shows there is a significant difference.

The results shows that majority of respondents $86.5 \%$ (173 respondents) supplement sand winning with other livelihood activities and the remaining $13.5 \%$ (27 respondents) maintain only sand winning. With $\mathrm{N}=200$, chi-square statistics $=11.12, \mathrm{df}=5$ asymp. sig. (2-sided) = 0.049, a null hypothesis of independence the categories of loading boys and drivers on complementing sand winning with other economic activities shows significant difference.

Respondents were asked to indicate whether they were satisfied with the earnings from sand winning. About 65.0\% (130 respondents) indicated no satisfaction, 1.5\% (3 respondents) reported low satisfaction, and 28.5\% (57 respondents) confirmed moderate satisfaction and 5.0\% (10 respondents) high satisfaction. The fact that 
sand winning entrepreneurs are not satisfied with their income is understandably so because greater part of the income goes to the truck and excavator owners. Loading boys and drivers earn their daily wage. Some drivers own the trucks in which case satisfaction of income is definitely high. The chi-square statistic is 16.0345 with a critical value of 7.815. The result is significant at 0.05 . Hence, there is significant variation in the responses of the two categories of respondents (loading boys and drivers).

The survey results included an analysis of income of sand producers in Tamale. It was discovered that sand producers consisting of both drivers and loading boys receive different wages. The results indicated that the minimum amount a sand winner earns in a day is GHS50.00 while the maximum daily income per a sand winner is GHS200.00. Averagely, it shows that the earning of a respondent is GHS82.00 and this has a standard deviation of 30.03 (Table 6).

Table 6: Income from and cost of sand winning

\begin{tabular}{|l|c|c|c|c|}
\hline \multicolumn{1}{|c|}{ Variables } & Min. & Max. & Mean & Std. Deviation \\
\hline Daily Income & 50.00 & 200.00 & 82.16 & 30.03 \\
\hline $\begin{array}{l}\text { Cost of a trip in sand winning in } \\
\text { the community }\end{array}$ & 118 & 250 & 184 & 93.33 \\
\hline $\begin{array}{l}\text { Price of a truck load of sand } \\
\text { in Tamale }\end{array}$ & 300.00 & 400.00 & 393.66 & 70.71 \\
\hline
\end{tabular}

In Table 7 the cost of a truckload of sand produced in the community which is 118 GHS is disaggregated (1USD = 5.7 GHS).

Table 7. Cost and sale of a trip of sand

\begin{tabular}{|l|c|c|c|}
\hline Variables & Cost (GHS) & \% & Sale (GHS) \\
\hline Loading boys & 50.00 & 42.4 & 300.00 \\
\hline Districts assembles & 5.00 & 4.2 & \\
\hline Traditional Authorities & 3.00 & 2.5 & \\
\hline Fuel & 50.00 & 42.4 & \\
\hline Police & 10.00 & 8.5 & \\
\hline \multicolumn{1}{|c|}{ Total } & 118.00 & 100 & 300.00 \\
\hline
\end{tabular}

The cost of fuel varies from one sand winning site to the other and consumption capacity of the various tipper trucks. However, majority of the respondents gave $\mathrm{GHS}_{50.00}$ as their fuel consumption for one trip. The difference between the cost and the sale is $\mathrm{GHS}_{1} 82$. 
Sand is retailed in Tamale. It is another source of income generation in the sand winning industry. Some entrepreneurs purchase a truckload of sand from the drivers and retail it using empty barrel/drum. Patronage comes from residents who needed smaller quantities of sand smaller than a truckload of sand. It was observed that sand winning business was booming in the city. A barrel of sand goes for 40 GHS and half a barrel of sand (20 GHS) (1UDS = $5.7 \mathrm{GHS}$ ).

\section{The Social Capital Possessed by the Sand Deposit Communities}

Opinion of household heads were sought on the relationships between sand producers and the residents of the sand winning communities on a likert scale of strongly disagree, disagree, neutral, agree, and strongly agree as shown in Table 8. Households in many instances have no prior agreement with sand winners operating on the lands. About $93.2 \%$ (55 respondents out of 59) reported that sand producers use force to mine sand. There is general consensus that the activities of sand winning are conflicting with their economic activities, particularly, farming. About 95\% agree and strongly agree that the activities of sand winning cause destruction to their farm lands. For example, the results of Peprah (2013) and Akko et al. (2014) show that destruction of farms, grazing lands and the collapse of river banks are the physical environmental impacts associated with mining of sand and gravel of which some communities suffer. Some 52.5\% (31 respondents) agreed that sand winning results in water shortage in the communities. In line with stability, this finding agrees with Monica and Murthy (2014) that the ill effect of sand winning on the environment includes degradation, lowering water table near stream bed and channel stability.

Table 8: Respondents' opinion on the social relationship of sand winning in their communities

\begin{tabular}{|l|c|c|c|c|c|c|}
\hline \multicolumn{1}{|c|}{ Activities } & SD & DA & Neutral & A & SA & Total \\
\hline $\begin{array}{l}\text { Extracting sand by } \\
\text { force }\end{array}$ & $55(93.2)$ & $\circ(0.0)$ & $0(0.0)$ & $4(6.8)$ & $0(0.0)$ & $59(100)$ \\
\hline $\begin{array}{l}\text { Stopped sand } \\
\text { producers }\end{array}$ & $3(5.0)$ & $0(0.0)$ & $2(3.4)$ & $28(47.5)$ & $26(44.1)$ & $59(100)$ \\
\hline $\begin{array}{l}\text { Destruction of } \\
\text { farmland }\end{array}$ & $0(0.0)$ & $\circ(0.0)$ & $3(5.0)$ & $26(44.1)$ & $30(50.9)$ & $59(100)$ \\
\hline Water shortage & $3(5.2)$ & $\circ(0.0)$ & $15(25.4)$ & $31(52.5)$ & $10(16.9)$ & $59(100)$ \\
\hline $\begin{array}{l}\text { Reclamation cost be } \\
\text { added to cost of sand }\end{array}$ & $0(0.0)$ & $\circ(0.0)$ & $0(0.0)$ & $26(44.1)$ & $33(55.9)$ & $59(100)$ \\
\hline $\begin{array}{l}\text { Must there be } \\
\text { regulatory body }\end{array}$ & $0(0.0)$ & $\circ(0.0)$ & $0(0.0)$ & $2(3.4)$ & $57(96.6)$ & $59(100)$ \\
\hline
\end{tabular}

Numbers in brackets are percentages. 
Opinions on whether reclamation cost be added to sand winning operations, $44.1 \%$ (26 respondents) agreed and 55.9\% (33 respondents) strongly agree that the cost of reclaiming the land be added to sand winning operations. Also, 3.4\% ( 2 respondents) agreed and $96.6 \%$ (57 respondents) strongly agreed that there must be a regulatory body to check the activities of sand winning.

Even though the sand winners go to the sand deposit communities to do business, it was revealed by the household heads that a social bond has been established in which the sand winners attend social gathering and ceremonies. Majority $83.1 \%$ (49 respondents) claimed sand producers attend funerals and naming ceremonies that take place 8 days after a baby is born. The remaining 16.9\% (10 respondents) mentioned provision of transportation for community member at no fares/fees. The views of household heads were complemented by that of sand producers $(n=200)$. About $38.5 \%$ (77 respondents) agreed and 26.5\% (53 respondents) strongly agreed that they provided transport services for the community members. The failure of these relationships suggest a problem between the two groups. Where force is used to get access to land for sand winning and when appropriate compensation are not paid to land owners cordial relationships are not expected.

Two drivers' associations were identified: (1) Water Works Tipper Drivers Union and (2) Zogbelle Tipper Drivers Union. However, the loading boys did not have unions. They work individually in response to their financial needs. A loading boy said:

Today I am a loading boy, tomorrow I may not be a loading, because if the pressing needs are solved with today's earnings I may not come here again. I will either rest or go to different work place. So I say that if you want to be a loading boy today, you just look for a shovel and move to any of the site that may be convenient to you.

The bi-directional relationship between researchers and their objects of research is referred to as reflexivity (Peprah, 2014). With the kind of development of houses/homes in Ghana, where individuals provide their houses with the use of local artisans of mason, carpenters, steel binders and others, and government development projects are done by construction contractors, the researchers are either on the demand or supply side of sand winning. Hence, researchers are part and parcel of the research objects in which case there is no separation between subject and object or knower and known.

The social environment refers to human or artificial environment and natural environment means ecosystem. Two issues are at play as human-in-nature in which 
social/human environment is embedded in the ecosystem. This is contrary to the second issue human-with-nature in which social/human environment stand sideby-side with the ecosystem. In both cases, human behaviour affects the ecosystem positively (cooperative/altruistic behaviour) and negatively (destructive behaviour). Found in the social/human environment is conservation and restoration of the ecosystem. There is bi-directional linkages between social/human and natural environment. Sand winning takes place in the natural environment to be used in the construction of Tamale for human use (social environment). For Tamale's development projects to continue, sand winning is needed, and it is imperative, therefore bi-directional relationship between the two cannot be skewed. In Nigeria, Adedeji et al. (2014) pointed out that an integrated environmental assessment, management and monitoring programme should be a part of any sand extraction operation and encourage at national, regional, district and local levels.

\section{The Sustainability Concerns Observed by Stakeholders}

From Table 9, 44.1\% (26 respondents) wants the use of excavators to produce sand to stop $(n=59)$. This finding is not in tune with technological optimism as postulated by ecological modernisation. Although, 38.9\% (23 respondents) want sand winners to get training which support technological optimism. Towards, sustainable production and consumption of sand is the issue of reclamation of degraded land which has been discussed earlier.

Table 9: Measures to ensure sustainable winning and consumption sand

\begin{tabular}{|l|c|c|}
\hline \multicolumn{1}{|c|}{ Sustainability measures } & Frequency & $\%$ \\
\hline Practicing good methods of sand producing & 2 & 3.4 \\
Avoid the use of Excavators & 26 & 44.1 \\
Provision of jobs & 3 & 5.1 \\
Training of sand producers & 23 & 38.9 \\
Avoid winning on unauthorised places. & 5 & 8.5 \\
\hline \multicolumn{1}{|c|}{ Total } & 59 & $\mathbf{1 0 0 . 0}$ \\
\hline
\end{tabular}

On the part of the sand producers ( $\mathrm{n}=200$ ), 78.5\% (157 respondents) support training of sand producers, $20 \%$ (40 respondents) by providing rules and regulations and out-right ban on sand winning by 1.5\% (3 respondents). On stakeholder involvement to ensure sustainable production and consumption of sand, majority of sand producers $85 \%$ (170 respondents) disagreed and the remaining 15\% (30 respondents) wants stakeholder participation in regulating sand winning. The involvement of stakeholder would influence sand winning activities through giving priority to 
environmental concerns. Stakeholders such as key community decision-makers noted that other households in the communities are dependent on agricultural land for livelihood and as such must be managed appropriately.

\section{CONCLUSION AND RECOMMENDATION}

\section{Conclusion}

The supply of sand for the developmental works in Tamale comes from communities outside Tamale Metropolitan area. An average of 54 truckloads of sand per day per site implies that large areas of sand deposited have been excavated in support of construction and development. The top soils (sand) is excavated leaving behind bad land's topography. Scarcity of sand in these communities implies the sand winners moving further away to look for sand deposits or river banks thereby increasing the distance between Tamale and sand mining sites. The sand is mined using different methods/technology. Preference is skewed towards the use of simple implements of pickaxe and shovel dependent on manual labour. Both sand winners and household heads in the sand deposit communities want the use of excavator for producing sand to stop in favour of environmental conservation. Hence, technological optimism as espoused in the theory of ecological modernisation is a forlorn hope.

Sand winning brings many economic benefits. Besides the entrepreneurs (truck and excavator owners), it provides employment for drivers and the youth as loading boys. The district assemblies of sand deposit communities benefit from revenues generated from taxes. Other beneficiaries include traditional authorities, fuel/ gas stations and the Police. There were improvements in the economic status of sand winners and loading boys. Seasonality of sand winning has been overcome by heaping of sand during the dry season on higher grounds to be transported and sold during raining season. A portion of the incomes is being saved and sand winners engage in additional income generating activities. The stakeholders observe the principles of free market capitalism. However, the state government has failed to support sand winning operations with guidelines and directives. The broad mining policy is applied to only highly value minerals such as gold, diamonds and others including granite rock quarrying.

The behaviour of sand winners operating a piece of land without negotiation with land owners is deemed as forceful entry and does not lead to cordial relationship between sand winning communities and sand winners. There is conflict between sand winning and agricultural livelihood options as sand winning destroys topsoil 
of farm lands. Water sources of sand deposit communities are adversely affected. Meanwhile, reclamation of degraded lands is not part of the deal. Where cordial relationship exists between sand winners and host communities, the former takes part in social ceremonies like naming ceremonies and funerals. Human agency is critical in the operation of sand winning for the development of Tamale. It is pivoted mainly on normative principles as legal principles supported by government are limited.

The results of the study further imply that the weakness associated with capacity building and law enforcement in sand producing operations threatens the sustainability of the business. Sand producers lack sustainable operations strategies because of lack of access to training programmes on their business. Besides, the relevant state institutions responsible for the regulation of the business have been weak and this implies that sand producing communities will continue to bear the cost of sand winning.

Considering the importance of sand in the constructional activities in developing countries including Ghana and the express objective of these countries to create sustainable environment, the laissez-faire approach to sand management should give way to objective management. This should begin with development of database for sand deposits. Data on all entrepreneurs could be added to the database together with the sand demand points and activities. An establishment by the Government of Ghana of a Sand Winning Agency would be advantageous to the state because such an institution would own and manage the database as well as regulate sand winning operations.

\section{REFERENCES}

Acharya, B .R. (2010). Urban Poverty: A Sociological Study of Shankhamul Squatter. Dhaulagiri Journal of Sociology and Anthropology, 4, 179-192.

Adedeji, O. H., Adebayo, H. A., \& Sotayo, E. I. (2014). Assessing the Environmental Impacts of Inland Sand producing. Ethiopian Journal of Environmental Studies \& Management, 7(5), $478-87 \leq \mathrm{http}$ //dx.doi.org/10.4314/ejesm.v7i5.2〉.

Agarwal, P. (2019). Characteristics of Developing Economies. Intelligent Economist, www.intelligenteconomist.com retrieved $28^{\text {th }}$ Jan 2020.

Akko, T. A., Onoduku, U. S., Oke, S. A., Idris, F. N., Umar, A. N., Ahmed, A. A., \& Abba, F. M. (2014). Environmental Effects of Sand and Gravel Mining on Land and Soil in Luku, North Central Nigeria. Global Journal of Science Frontier Research: 
H Environment \& Earth Science., 14(12), 42-49<http://creativecommons.org/ licenses/by-nc/3.0/.

Amponsah-Dacosta, F., \& Mathada, H. (2017). Study of Sand producing and Related Environmental Problems along the Nzhelele River in Limpopo Province of South Africa. In C. Wolkersdorfer, L. Sartz, M. Sillanpää \& A. Häkkinen (Eds) Mine Water and Circular Economy. (pp.1259-1266). IMWA. imwa.info/docs/ imwa_2017/IMWA2017_Amponsah-Dacosta_1263.pdf

Andersen, M. S., \& Massa, I. (200o). Ecological Modernisation: Origins, Dilemmas and Future Directions. Journal of Environmental Policy \& Planning, 2, 337-45.

Arwa, G. A. (2013). Sustainable Governance for Artisanal Sand Mining Case of Kangonde Location, Masinga District. Nairobi, Kenya: University of Nairobi.

Asoka, G. W. N., Thuo, A. D. M., \& Bunyasi, M. M. (2013). Effects of Population Growth on Urban Infrastructural Services: A Case of Eastleigh Neighbourhood Nairobi, Kenya. Journal of Anthropology \& Archaeology, 1(1), 41-56.

Berger, G., Flynn, A., Hines, F., \& Johns, R. (2001). Ecological Modernisation as a Basis for Environmental Policy: Current Environmental Discourse and Policy and the Implications on Environmental Supply Chain Management. Innovation, 14(1), 55-72.

Cobbinah, P. B., \& Erdiaw-kwasie, M. O. (2016). Urbanization in Ghana: Insights and Implications for Urban Governance. In Benna, U. G. \& Garba, S. Population Growth and Rapid Urbanization in the Developing World [pp. 85-108]. IGI Global. DOI - 10.4018/978-1-5225-0187-9.Choo5.

Fuseini, I., \& Kemp, J. (2016). Characterising urban growth in Tamale, Ghana: An analysis of urban governance response in infrastructure and service provision. Habitat International 56, 109-123

Fuseini, I., Yaro, J. A., \& Yiran, G. A. B. (2017). City profile: Tamale, Ghana. Cities, $60,64-74$.

GSS. (2012). 2010 population and housing census. Summary report of final results. Ghana Statistical Service Sakoa Press Limited.

GSS. (2014). Housing in Ghana: 2010 Population and Housing. Ghana Statistical Service Sakoa Press Limited

JICA. (2013). Development Challenges in Africa towards 2050. Japan International Cooperation Agency

Kpieta, A. B., \& Bonye, S. (2012). Land as a "god": The gender dimensions of its wealth creation among the Dagaabas in North-Western Ghana. European Scientific Journal, 8(14), 109-131. https://doi.org/10.19044/esj.2012.v8n14p\%p 
Langhelle, O. (2000). Why Ecological Modernisation and Sustainable Development Should Not Be Conflated. Journal of Environmental Policy \& Planning, 2, 303-22.

MLGRD. (2012). Ghana National Urban Policy Action Plan, Accra, Ministry of Local Government and Rural Development. Accra, Ghana: Ministry of Local Government and Rural Development

Mol, A. P. J., \& Spaargaren, G. (2000). Ecological Modernisation Theory in Debate: A Review. Environmental Politics, 9(1), 17-49.

Mol, A. P. J., Spaargaren, G., \& Sonnenfeld, D. A. (2014). Ecological Modernisation Theory: where do we stand? In M. Bemmann, Metzger, B., von Detten, R., (Eds.), Okologische Modernisierung-Zur Geschichte und Gegenwarteines Konzept in Unweltpolitik und Sozialwissenschafter, (pp. 1-32). Environmental Policy WASS WIMEK. https://www.researchgate.net/publication/265292892 ).

Monica, U., \& Murthy, A. (2014). Sand producing: Curbing the Evil to the Environment through Sustainable Substitution and Legislative Action. OIDA International Journal of Sustainable Development, o7(03), < http://www.ssrn.com/link/OIDAIntl-Journal-Sustainable-Dev.html>.

Peduzzi, P. (2014). Sand, Rarer Than One Thinks. Environmental Development, 11, 208-218. 10.1016/j.envdev.2014.04.001

Peprah, K. (2013). Sand Winning and Land Degradation: Perspective of Indigenous Sand Winners of Wa, Ghana. Journal of Environment and Earth Science, 3(14), 185-94.

Peprah, K. (2014). Knowledge Production Contest between Natural and Social Scientists with Regards to Land Degradation Assessment. The Journal of Arts and Philosophy, 2(1), 5-11.

Raghavendra, N. S. A. M., \& Hans, V. B. (2012). Infrastructural Challenges of Urbanisation. Ideas \& Ideologies (I\&I) International E-Journal, 2(5), 1-19.

Rosa, E., Diekmann, A., Dietz T., \& Jaeger, C. (2010). 'Human Footprints on the Global Environment: Threats to Sustainability', (Cambridge: MA: MIT Press).

Salifu, B. (2016). Implications of Sand producing on the Environment and Livelihoods in Brong Ahafo Region. Kumasi, Ghana: Kwame Nkrumah University of Science and Technology.

Saviour, M. N. (2012). Environmental impact of soil and sand producing: A review. International Journal of Science, Environment and Technology, 1(3), 1250-134.

Sayami, M., \& Tamrakar, N. K. (2007). Status of sand producing and quality in northern Kathmandu, Central Nepal. Bulletin of the Department of Geology, 10, 89-98. 
Sumani, J. B. B. (2019). Possible Environmental and Socio-economic Ramifications of Sand and Gravel Winning in Danko, Upper West Region of Ghana. Ghana Journal of Geography, 11(2), 27-51.

Town and Country Planning Department. (2014). Tamale Northern Region of Ghana. Town and Country Planning Department.

Trochim, W. M. K. (2006). Positivism and Post-Positivism. The Research Methods Knowledge Base. Cincinnati, OH, USA: Web Center for Social Research Methods.https://conjointly.com/kb/positivism-and-post-positivism/

UN. (2019). World Urbanization Prospects: The 2018 Revision. United Nations [UN].

United Nations Human Settlements Programme. (2003). The Challenge of Slums Global Report on Human Settlements 2003. United Nations Human Settlements Programme.

WHO. (2013). Cities and the Population Issue. World Health Organisation.

WHO. (1991). Technical Discussions on Strategies for Health for All in the Face of Rapid Urbanization. World Health Organization [WHO].

World Bank. (2014). Rising through Cities in Ghana, Ghana Urbanisation Review: Overview Report. The World Bank.

World Bank. (2017). Africa's Cities Opening Doors to the World: Overview. The World Bank. 